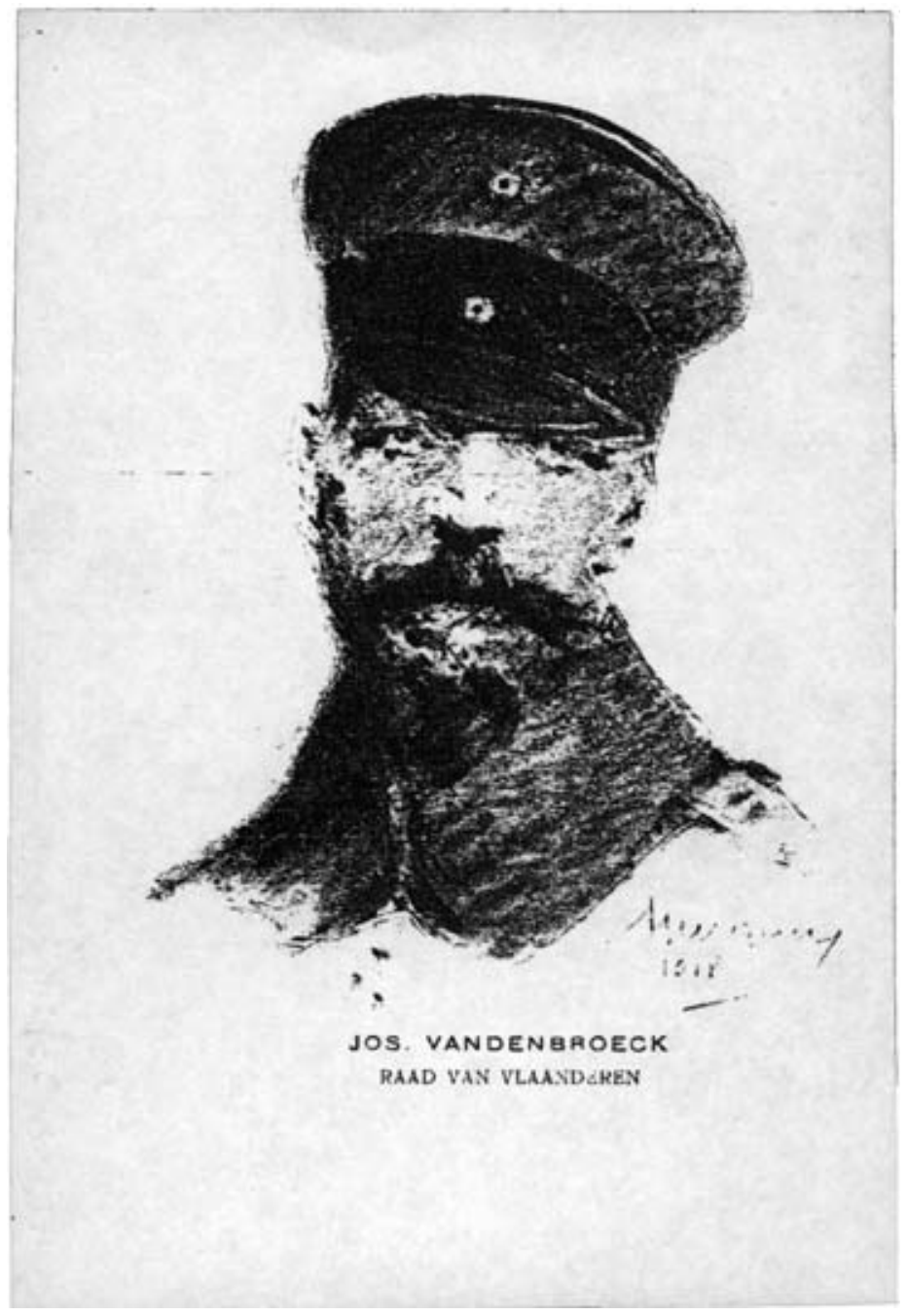

Spotprent van Jozef Van den Broeck als lid van de Raad van Vlaanderen. [ADVN, VPA468/3] 


\section{Jozef Van den Broeck, flamingant en informant (1870-1938)}

Na de Duitse ineenstorting in 1918 werd Nederland het toevluchtsoord voor een aanzienlijk aantal Vlaams-nationalistische collaborateurs. De Nederlandse staat was bereid asiel te verlenen aan activisten aangezien zij in het bevrijde België blootstonden aan het risico op vervolging. Hij wenste wel controle uit te oefenen over de instroom om te verhinderen dat economische vluchtelingen, communistische agitatoren en Belgische inlichtingenagenten van de vlucht van de activisten gebruik zouden maken om zich in Nederland te vestigen. Zulks vergde een diepgaande kennis over het activistische milieu. De Nederlandse overheden beschikten vanzelfsprekend niet over die kennis. Jozef Van den Broeck was vanwege zijn oorlogsverleden de geknipte persoon om de Nederlandse staat van inside information over het activisme te voorzien. In deze bijdrage wordt ingegaan op zijn activiteiten als informant voor het Nederlandse staatsapparaat in de jaren na de Eerste Wereldoorlog. Vanzelfsprekend kan hierbij een korte schets van de voorgeschiedenis, waarin Van den Broeck zijn gewaardeerde kennis opbouwde, niet ontbreken. ${ }^{1}$

\section{EEN MILITANT VAN DE NEDERDUITSCHE BOND}

Jozef Van den Broeck werd op 26 november 1870 in Antwerpen geboren. Hij volgde de humaniora aan het Onze-Lieve-Vrouwecollege waar op dat ogenblik ook Adolf Pauwels en Adelfons Henderickx schoolliepen. Hij werd lid van de flamingantische scholierenkring Eigen Taal, Eigen Zeden die in september 1887 opgericht werd. ${ }^{2} \mathrm{Na}$ de middelbare school ging Van den Broeck rechten studeren aan de Leuvense universiteit. In Leuven kwam hij weer in contact met Henderickx die in oktober 1888 het veertiendaagse tijdschrift Ons Leven, als tolk van de katholieke Vlaamse studenten, oprichtte. ${ }^{3}$ Vanaf de tweede jaargang werd Van den Broeck redacteur van het studentenblad waarin hij schreef onder het pseudoniem Kaerel Verdietsch. Samen met Henderickx was hij ook betrokken bij pogingen om

1. Tekst gebaseerd op Y. Geenen, Jozef Van den Broeck. Flamingant, activist, banneling, KULeuven, departement Geschiedenis, licentiaatsverhandeling, 2003.

2. L. Gevers, Bewogen jeugd. Ontstaan en ontwikkeling van de Katholieke Vlaamse studentenbeweging (1830-1914), Leuven, 1987, pp. 179-180.

3. L. Vos \& L. Gevers, De Vlaamse studentenbeweging te Leuven (1836-1914), in: Onze Alma Mater, jg. 29, 1975, nr. 2, p. 120. 
tot een overkoepelende Vlaams katholieke studentenvereniging te komen. Ze namen deel aan verschillende vergaderingen met diverse studentenleiders, die op 19 augustus 1889 uitmondden in de oprichting van het Katholiek Vlaams Studentenverbond. ${ }^{4}$

Intussen was Van den Broeck lid geworden van de Nederduitsche Bond, de flamingantische vleugel van de Antwerpse Meetingpartij. Op 5 april 1890 had Flor Peeters hem samen met Henderickx op de bestuurszitting van de bond voorgedragen als lid. Van den Broeck trad daarmee in de voetsporen van zijn vader Frans, die op dat ogenblik lid van het bestuur was. ${ }^{5}$ Twee jaar later deed hij een vergeefse gooi naar een zitje in het bestuur van de bond. ${ }^{6}$ Naderhand zou Van den Broeck toch nog bestuurslid worden, maar wanneer precies is onduidelijk.

$\mathrm{Al}$ dan niet in het bestuur, Van den Broeck legde zich al snel toe op het zogenaamde 'Grievenkomiteit'. Zijn taak bestond erin om alle mogelijke inbreuken op de taalwetten of schendingen van het Nederlandse karakter van Vlaanderen te rapporteren op de algemene vergaderingen van de Nederduitsche Bond. De parlementsleden, provincieraadsleden en gemeenteraadsleden konden de grieven dan voorleggen aan de bevoegde instanties. In 1892 en 1893 stelde Van den Broeck zo het taalgebruik op tentoonstellingen, het landjuweel en de aanstaande wereldtentoonstelling van Antwerpen aan de orde. ${ }^{7}$ Hij ontpopte zich tot een gedreven militant die met zijn inzet de realisatie van het flamingantische program langs reformistisch-wettelijke weg dichterbij wenste te brengen. In hetzelfde perspectief moeten zijn activiteiten als propagandist gezien worden. Van den Broeck stichtte in 1893 samen met Henderickx de sprekersafdeling van de Nederduitsche Bond, Het Vrije Woord. In het vooruitzicht van de invoering van het Algemeen Stemrecht was het immers van kapitaal belang nieuwe kiezers binnen te halen. ${ }^{8}$

In 1895 werd Van den Broecks inzet beloond met zijn verkiezing tot het bureau. Henderickx en hij werden de secretarissen van de bond. Hij behield de post tot in 1897. In dat jaar voerde hij actief propaganda voor de Gelijkheidswet. Van den Broeck raakte ook betrokken bij de publieke uitingen van flamingantische Boeren-

4. L. Gevers, Bewogen [...] , pp. 187-195. M. Cordemans, Dr. August Laporta en 'de student', Leuven, 1959, pp. 237-247.

5. AMVC-Letterenhuis, Archief Nederduitsche Bond, B714: Bijvoegsel van de bestuurszitting van 5 april 1890.

6. AMVC-Letterenhuis, Archief Nederduitsche Bond, B714: Reglement van de Nederduitsche Bond; Aankondiging bestuursverkiezing, 4 juli 1892; Het Handelsblad van Antwerpen, 5 juli 1892 (verslag van de algemene vergadering van de Nederduitsche Bond); Het Recht, 10 juli 1892 (uitslag van de verkiezingen).

7. Het Handelsblad van Antwerpen, 29 november 1892 en 9 mei 1893 (Verslagen van de algemene vergadering van de Nederduitsche Bond).

8. L. Wils, De politieke ontwikkeling in België 1894-1914, in: D.P. Blok, e.a. (red.), Algemene Geschiedenis der Nederlanden, Haarlem, 1978, dl. 13, p. 396. 
sympathie naar aanleiding van de Tweede Boerenoorlog. Hij vertegenwoordigde de Nederduitsche Bond op een Antwerpse Meeting voor Transvaal op 17 september 1899. De vergadering resulteerde in het Hulp-comiteit voor Transvaal, met Pol De Mont als voorzitter en Van den Broeck en Adolf Pauwels als ondervoorzitters. De vereniging zamelde geld in ten voordele van een ambulance die op 25 november 1899 vanuit Amsterdam naar Zuid-Afrika vertrok. Het comité vormde de grondslag van de Antwerpse tak van het Algemeen Nederlands Verbond (ANV) waarvan Van den Broeck tweede schrijver werd. ${ }^{9}$ In hetzelfde jaar werd ook het weekblad Ons Recht opgericht, de opvolger van het in 1894 ter ziele gegaan Het recht. Van den Broeck werd redacteur van het blad, dat het officieuze partijblad van de Nederduitsche Bond werd.

De taalregeling in het vrij middelbaar onderwijs was een onderwerp dat Jozef Van den Broeck na aan het hart lag. In de Nederduitsche Bond had hij al in 1894 op een regeling aangedrongen. Hij zou samen met zijn vriend Adelfons Henderickx, die in 1906 parlementslid werd, binnen de Nederduitsche Bond het voortouw nemen in de strijd voor het wetsvoorstel-Coremans van 1901, dat aanstuurde op een versterking van de positie van het Nederlands in het gehele middelbaar onderwijs, dus met inbegrip van het vrij onderwijs. ${ }^{10}$ Het episcopaat zag in het voorstel een aantasting van de vrijheid van onderwijs en een ondergraving van zijn gezag. De nieuwe aartsbisschop Mercier drong met die argumenten aan op de intrekking van het wetsvoorstel en stelde daartegenover dat hij op eigen initiatief de positie van het Nederlands in het vrij middelbaar onderwijs zou versterken. Merciers zet verdeelde de katholieke flaminganten. Van den Broeck behoorde tot de radicale strekking die het wetsvoorstel-Coremans wenste door te drukken zonder acht te slaan op Merciers voorstel. Ook naar aanleiding van het verschijnen van de bisschoppelijke verordeningen inzake het taalgebruik in het onderwijs, stelde Van den Broeck zich radicaal op en aarzelde hij niet om de confrontatie met het episcopaat aan te gaan. Het is dan ook niet verwonderlijk dat Van den Broeck eveneens vooraan stond bij de protesten naar aanleiding van de parlementaire begraving van het wetsvoorstel-Coremans in 1907. Hij schoof de schuld voor het debacle nadrukkelijk in de schoenen van de Vlaamse katholieken

9. D. Luyckx, Adolf Pauwels en de Vlaamse Volkspartij, in: L. Wils (red.), Kopstukken van de Vlaamse Beweging: Jan van Rijswijck, Adolf Pauwels, Louis Franck: Biografische studies, Kortrijk, 1978, pp. 262-263.

10. ADVN, Archief Jozef Van den Broeck, AC451, D1858(1), dossier Henderickx: Brief van Adelfons Henderickx aan Jozef Van den Broeck, 21 januari 1938; AMVC-Letterenhuis, Archief Jozef Van den Broeck, B8714: Brief van Jozef Van den Broeck aan Adelfons Henderickx, 2 mei 1926; Ons Recht, 19 augustus 1906 (verslag van de landdag); Ons Recht, 23 juni 1907 (verslag van de protestmeeting); Ons Recht, 14 juli 1907 (verslag van de grote protestmeeting, in bijvoegsel). Voor de algemene context zie H. Van Velthoven, De Vlaamse kwestie 1830-1914: macht en onmacht van de Vlaamsgezinden, Kortrijk, 1982, pp. 135-177; L. Wils, De Messias van Vlaanderen. Frans van Cauwelaert 1880-1910, Antwerpen-Baarn, 1998, pp. 62-72 en 111-128. 
in het parlement, die hun beloften niet nagekomen zouden zijn. Het betreft hier een vroege uiting van het latente antiparlementarisme dat in de rangen van de flaminganten zou sluipen. Toch haakte Van den Broeck niet ontgoocheld af. De uiteindelijke taalwet van 1910 waardoor het dossier gedeblokkeerd werd en de essentie van het flamingantische program bereikt werd, kon hem blijkbaar enigszins bevredigen. Zo was hij als lid van de Vlaamse Hogeschoolcommissie betrokken bij de strijd voor de vernederlandsing van de Gentse universiteit die in 1910 losbarstte. Naar aanleiding van het legerontwerp-de Broqueville in 1912 ijverde Van den Broeck op een vergadering van de Katholieke Vlaamse Landsbond samen met Frans Van Cauwelaert (met wie hij naar aanleiding van het voorstelCoremans nog gebotst had) en Alfons Van de Perre voor het openhouden van de piste van een 'geleidelijke politiek'. ${ }^{11}$ Hij keerde zich hiermee tegen de radicalen (onder anderen zijn vriend Adelfons Henderickx) die de onmiddellijke oprichting van Vlaamse en Waalse regimenten eisten. Of Van den Broeck als gevolg van het teleurstellende resultaat van de leger- en de schoolwet in 1913 en 1914 zijn houding bijstelde, is onbekend. Binnen zijn politieke milieu, de Nederduitsche Bond, vertaalde het flamingantisch en antimilitaristisch gemotiveerde ongenoegen over de resultaten van de parlementaire weg zich tijdens de laatste vooroorlogse maanden in de groei van een antipolitiekgetinte oppositiestroming, die open begon te staan voor radicalere oplossingen van de Vlaamse kwestie. ${ }^{12}$ Pleidooien werden gehouden voor flamingantische partijvorming. De 'bestuurlijke scheiding' die in 1912 naar aanleiding van de brief van Jules Destrée nog afgewezen werd, begon de geesten te beroeren.

\section{COLLABORATIE ZONDER VOORBEHOUD}

De ontgoocheling bij een aantal radicale flaminganten over de resultaten van de parlementaire weg zou een van de voedingsbodems vormen waarin het activisme kon kiemen. In Antwerpen kwam het activisme echter relatief langzaam op gang. ${ }^{13}$ De vlucht vooruit van de collaboratie oefende in de 'hoofdstad van de Vlaamse beweging' een geringere aantrekkingskracht uit dan elders. De Vlaamse beweging had er immers haar grootste vorderingen gemaakt. De Scheldestad vormde bovendien het brandpunt van de flamingantische parlementaire activiteit. Toen August Borms in het vroege voorjaar van 1915 definitief in de collaboratie stapte, stond hij

11. H. Van Velthoven, De Vlaamse kwestie [...], p. 304.

12. H. Van Velthoven, De Vlaamse kwestie [...] , p. 356.

13. Zie voor het Antwerpse activisme: A. Vrints, Bezette stad. Vlaams-nationalistische collaboratie in Antwerpen tijdens de Eerste Wereldoorlog, Brussel, 2002. Specifiek voor het ontstaan zie ook D. Luyckx, Adelfons Henderickx en het activisme in Antwerpen tijdens de Eerste Wereldoorlog - I: In 1914, in: Wetenschappelijke tijdingen, jg. 53, 1994, nr. 1, pp. 21-33 en D. Luyckx, Adelfons Henderickx en het activisme in Antwerpen tijdens de Eerste Wereldoorlog - II: In 1915, in: Wetenschappelijke tijdingen, jg. 55, 1996, nr. 2, pp. 91-109. 
in Antwerpen nagenoeg alleen en dat bleef nog lange tijd zo. Jozef Van den Broeck zou als een van de eersten Borms' zijde kiezen. Hij was van meet af aan betrokken bij de redactie van Antwerpen Boven. Orgaan der Groeningerwachten van Antwerpen en Omstreken, een halfmaandelijks blad dat midden april 1915 voor het eerst verscheen en de flaminganten aanspoorde de vaderlandse godsvrede te doorbreken. Van den Broeck was ook betrokken bij Borms' pogingen om het dagblad Het Vlaamsche Nieuws in handen te krijgen. ${ }^{14}$

Over de precieze motieven van Van den Broeck bestaat geen duidelijkheid. Zoals gezegd is het onbekend of hij net voor de oorlog tot de oppositiegroep binnen de Nederduitsche Bond behoorde. Wel zou hij zich reeds voor de oorlog uitgelaten hebben voor de 'bestuurlijke scheiding'. Mogelijk speelden oude antien sympathieën ten aanzien van de oorlogvoerende partijen een rol bij Van den Broecks positiebepaling. Het wantrouwen ten aanzien van Frankrijk was endemisch in het katholieke Vlaamsgezinde milieu. Gezien Van den Broecks actieve steun aan de Boeren, is er weinig reden om hem van anglofilie te verdenken. Daarenboven ontwikkelde hij een zekere germanofilie. Zo hield hij voor de oorlog enkele spreekbeurten over Duitse literatuur. ${ }^{15}$

Toen de bezetter de vernederlandsing van de Gentse universiteit afkondigde, ontpopte Van den Broeck zich tot een actief propagandist ervan. Samen met Adelfons Henderickx begon hij het weekblad De Eendracht dat op 3 september 1916 voor het eerst verscheen en propaganda moest voeren voor de Gentse hogeschool. ${ }^{16}$ Het stelde zich gematigd op om de talrijke katholieke loyale flaminganten voor de activistische zaak te kunnen winnen. De publicatie van het eerste manifest van de Raad van Vlaanderen en van een aankondiging voor vrijwillige tewerkstelling in Duitsland, laat echter weinig onduidelijkheid bestaan over de eigenlijke agenda van het blad. Terwijl voor Adelfons Henderickx dergelijke stellingname een stap te ver was en een reden tot ontslag vormde, stemde zijn vriend Van den Broeck in met die koers. ${ }^{17}$ Volgens een naoorlogse getuigenis van de drukker van het blad op het proces-Henderickx, trad Van den Broeck veelvuldig als verbindingsman met de Duitse censuur op. Of hij betaald werd voor zijn redactiewerk is onbekend, maar erg waarschijnlijk.

14. L. Wils, Flamenpolitik en aktivisme, Vlaanderen tegenover België in de Eerste Wereldoorlog, Leuven, 1974, pp. 100-101.

15. R. Victor, Schets ener geschiedenis van de Geschiedenis van de Vlaamse Conferentie der Balie van Antwerpen, 1885-1900, Antwerpen, 1960, pp. 180, 194 en 200.

16. W. Van Daele \& H. Mommaerts, Eendracht, de, in: R. De Schryver, e.a. (red.), Nieuwe Encyclopedie van de Vlaamse Beweging (NEVB), Tielt, 1998, dl. 1, pp. 1049-1050.

17. Hofvan Assisen van Antwerpen. 10, 11, 12, 13 en 14 November 1919. Zaak Adelfons Henderickx. Acte van Beschuldiging, Ondervraging, Getuigenverhoor, Requisitorium en Pleidooien, SintNiklaas-Waas, 1919. 
De onvoorwaardelijkheid van Van den Broecks collaboratie blijkt wel uit het feit dat hij van meet af aan betrokken was bij de Raad van Vlaanderen, het lichaam dat door de bezetter in het leven geroepen was om als Duitse handpop op het internationale toneel ingezet te kunnen worden. ${ }^{18}$ Via zijn contacten met de bezetter was hij goed op de hoogte van de langetermijndoelstellingen van de Flamenpolitik (de vernietiging van België, een blijvende Duitse militaire aanwezigheid, de Angliedering van Groot-Nederland bij Duitsland) en hij stemde er blijkbaar mee in. Een notitie uit het dagboek van zijn vriend Adelfons Henderickx laat aan duidelijkheid niets te wensen over: "De indruk die Van den Broeck van dat alles meebracht is: 'De Duitsers houden hier een bezetting na den oorlog. Kant en klaar is de uitwerking van 't beginsel der Bestuurlijke Scheiding. De uitwerking ervan staat reeds gans in beeld voor den geest. Het zal zijn voorlopige scheiding van tafel en bed (bestuurlijke scheiding) om tot de echtscheiding te komen ... en later vereniging met Holland (???)'. "19 Enige reserve legde Van den Broeck bij zijn contacten met de bezetter niet aan den dag. Hij beroemde er zich zo ten aanzien van Henderickx op dat hij de Duitse kanselier Moritz von Bissing had weten te charmeren met een complimentje. ${ }^{20}$ Aangemoedigd door Ludwig Hürter, de aalmoezenier van het Duitse garnizoen in Antwerpen, Thaddée Spaeninkx, een activistisch priester, en Konrad Beyerlé, medewerker van de Politische Abteilung in Brussel, maakte hij deel uit van de delegatie van de Raad van Vlaanderen die op 3 maart 1917 door de kanselier in Berlijn werd ontvangen. ${ }^{21}$

Van den Broeck besefte goed dat het initiatief tot de oprichting van de Raad van Vlaanderen, de reis naar Berlijn en de bekendmaking ervan ingegeven werden door het Duitse strategische belang, maar zulks weerhield hem er niet van steeds verder door te gaan op de ingeslagen weg. ${ }^{22}$ Vanaf begin 1917 werd hij ook voor zijn levensonderhoud afhankelijk van de collaboratie. Na de oorlog claimden de Belgisch-nationalistische uitgevers van het archief van de Raad van Vlaanderen dat Van den Broeck door de cumulatie van functies 18500 frank per jaar opstreek, een cijfer dat aan Vlaams-nationalistische zijde betwist werd. ${ }^{23}$ Van den Broeck

18. AMVC-Letterenhuis, Archief Adelfons Henderickx, H504: Dagboek, 17 januari 1917 en 2 februari 1917. A. Faingnaert, Verraad of zelfverdediging? Bijdragen tot de geschiedenis van den strijd voor de zelfstandigheid van Vlaanderen tijdens den oorlog van 1914-18, Kapellen, 1932, pp. 515-517 en 520-530.

19. AMVC-Letterenhuis, Archief Adelfons Henderickx, H504: Dagboek, 19 februari 1917. 20. AMVC-Letterenhuis, Archief Adelfons Henderickx, H504: Dagboek, 13 februari 1917. 21. A. Faingnaert, Verraad [...], pp. 540-545. D. Luyckx, Het omzichtig activisme van Adelfons Henderickx in de winter van 1916-1917, in: Wetenschappelijke tijdingen, jg. 61, 2002, nr. 2, p. 75. Over de rol van K. Beyerlé in de opbouw van het katholieke activisme zie W. Dolderer, Deutscher Imperialismus und belgischer Nationalitätenkonflikt: die Rezeption der Flamenfrage in der deutschen Öffentlichkeit und deutsch-flämische Kontakte 1890-1920, Melsungen, 1989, pp. 182-192.

22. AMVC-Letterenhuis, Archief Adelfons Henderickx, H504: Dagboek, 6 maart 1917.

23. A. Faingnaert, Verraad [...] , pp. 591-592. 
verhuisde naar Brussel, zetelde in het bestuur van de Raad van Vlaanderen en werd op 25 maart 1917 samen met Achiel Brijs, secretaris van de raad. ${ }^{24}$ Terwijl Brijs de interne keuken van de raad verzorgde, legde Van den Broeck zich toe op de externe contacten van de raad. De facto trad hij op als verbindingsman tussen de raad en de bezetter. Hoe nauw de relaties met de bezetter wel werden, blijkt uit de participatie van Van den Broeck in de rouwstoet bij het overlijden van Von Bissing op 20 april $1917 .{ }^{25}$

Om levensbeschouwelijke redenen stond Van den Broeck wantrouwig tegenover de Jong-Vlamingen binnen de raad. ${ }^{26} \mathrm{Hij}$ vermoedde achter hun optreden machinaties van de loge die zou aansturen op het failliet van het activisme. Hij behoorde tot de katholieke activistische vereniging Vrij Vlaanderen, die opgericht werd om weerwerk te bieden aan het Belgische nationalisme van kardinaal Mercier en die via levensbeschouwelijke profilering katholieke Vlaamsgezinden moest lijmen voor de collaboratie. ${ }^{27}$ Op staatkundig vlak streefde Vrij Vlaanderen hetzelfde, separatistische program na als Jong-Vlaanderen. Ook Van den Broeck kan bezwaarlijk als een gematigd activist betiteld worden. Hij zetelde in de activistische Gouwraad van Brabant die op termijn het wettelijke provinciebestuur moest vervangen, drong samen met de activistische Commissie van Gevolmachtigden aan op de deportatie van tegenstanders uit de politieke en gerechtelijke wereld en steunde op 28 maart de motie in de Raad van Vlaanderen, waarin geëist werd dat de naam 'België' verdween. Intussen bleef hij, ondanks enkele onderbrekingen, secretaris van de Raad van Vlaanderen en van 22 december 1917 af was hij algemeen opziener bij het te splitsen Ministerie van Rechtswezen.

Zoals genoegzaam bekend, betekende de Duitse ineenstorting niet het onmiddellijke einde van de Flamenpolitik.$^{28}$ De Duitse gouverneur-generaal stelde in september 1918 uit betrouwbare activisten een Commissie van Zaakgelastigden samen die de ondergang van de collaboratie moest begeleiden en de toekomst moest voorbereiden. Midden oktober $1918 \mathrm{kreeg}$ die de raad om naar Nederland uit te wijken om vandaar uit, met het oog op de verhoopte vredesconferentie, propaganda te blijven voeren voor een zelfstandig Vlaanderen. Om strategische redenen was de vestiging van de activistische vluchtelingen voor de Duitse overheden in Nederland veel interessanter dan in Duitsland. Activisten die aanvankelijk de wijk hadden genomen naar Duitsland, werden zo in de mate van het mogelijke

24. A. Faingnaert, Verraad [...], p. 563.

25. A. Faingnaert, Verraad [...], pp. 578-579.

26. AMVC-Letterenhuis, Archief Adelfons Henderickx, H504: Dagboek, 23 mei 1917. A. Faingnaert, Verraad [...], pp. 587-588.

27. L. Vandeweyer, Kiezen tussen Kardinaal en Kaiser. Vlaamse katholieken tijdens de Eerste Wereldoorlog, in: Trajecta, jg. 5, 1996, nr. 2, pp. 139-140.

28. D. Vanacker, Het aktivistisch avontuur, Gent, 1991, pp. 341-342. L. Wils, Vlaanderen, België, Groot-Nederland. Mythe en geschiedenis, Leuven, 1994, pp. 284-285. 
naar Nederland doorgesluisd. Vanuit het neutrale Nederland zou de stem van de activistische ballingen ten overstaan van het Belgische en internationale publiek veel geloofwaardiger in een Vlaams/Groot-Nederlands kleedje gehuld kunnen worden dan vanuit Duitsland ooit het geval zou kunnen zijn. De vestiging van een groep uitgesproken anti-Belgische bannelingen had het bijkomende voordeel dat een spoorslag gegeven kon worden aan de anti-Belgische, Groot-Nederlandse beweging in Nederland en dat een stoorzender werd gecreëerd in de BelgischNederlandse relaties. Er werd een Vlaams comité gevormd dat de activistische propaganda in Nederland moest coördineren en door de Duitsers gefinancierd werd met belastingopbrengsten uit het bezette land. Het bestond uit een aantal zaakgelastigden en Willem De Vreese en Jozef Van den Broeck, respectievelijk voorzitter en secretaris van de Raad van Vlaanderen.

\section{EEN ANTI-BELGISCH MILITANT IN NEDERLAND}

Toen het in de herfst van 1918 eenmaal duidelijk werd dat het fundament van het activisme, de Duitse militaire macht, weggeslagen werd, vluchtte ook Jozef Van den Broeck naar Nederland. Wanneer precies is onduidelijk. Op 9 november was hij nog op post in Brussel. ${ }^{29}$ Bij verstek werd Van den Broeck voor zijn aandeel in het activisme door de Belgische justitie ter dood veroordeeld. Net als voor vele andere voormalige activisten, verliep ook voor hem de integratie in de Nederlandse samenleving verre van rimpelloos. Zijn rechtendiploma was er immers waardeloos. Om zijn beroep weer te kunnen uitoefenen, zou hij zijn studie over moeten doen aan een Nederlandse universiteit. Hij had even de intentie om dat inderdaad te doen, maar hij deed het uiteindelijk niet omdat hij het niet kon betalen..$^{30}$ De eerste maanden in Nederland kwam hij rond met het geld dat hij had verdiend met zijn lucratieve baan bij de Raad van Vlaanderen. Hij had nog langer op zijn reserves kunnen teren als hij niet getalmd had om zijn marken om te zetten in guldens. Uiteindelijk moest hij als gevolg van de voorthollende inflatie in Duitsland zijn marken tegen een lage koers verkopen. ${ }^{31}$

Op 31 maart 1920 ging Van den Broeck als klerk aan de slag bij boekhandel Mensing. ${ }^{32}$ Qua verloning en prestige een hele stap terug in vergelijking met zijn vroegere advocatenbestaan in Antwerpen. Van den Broeck kreeg te kampen met neerslachtigheid en medische problemen, wat hem gedurende zekere tijd belette

29. AMVC-Letterenhuis, Archief Raad van Vlaanderen, R1008, map 9.

30. ADVN, Archief Jozef Van den Broeck, AC451, D1958(1), dossier Henderickx: Brief van Jozef Van den Broeck aan Adelfons Henderickx, 14 mei 1922.

31. AMVC-Letterenhuis, Archief Jozef Van den Broeck, B8714: Brief van Jozef Van den Broeck aan Adelfons Henderickx, 14 augustus 1922.

32. ADVN, Archief Jozef Van den Broeck, AC451, D1957(1): Dagboek Jozef Van den Broeck, 31 maart 1920. 
te werken. ${ }^{33}$ Pas in 1925 slaagde hij erin een beter betaalde baan te vinden bij de Berlitzschool in Den Haag. Hij verdiende er 45 gulden per week, wat dubbel zoveel was dan wat hij eerder bij boekhandel Mensing kreeg. Het gaf hem de kans om zijn precaire financiële toestand aan te zuiveren. ${ }^{34}$ Later ging hij ook elders aan de slag als leraar. Hij gaf privéles bij de Amerikaanse gezant in Nederland en bij andere prominenten. ${ }^{35}$ Uiteindelijk vond hij een vaste baan bij de Haagse katholieke krant De Residentiebode. Het is echter niet volledig duidelijk wanneer hij bij de krant in dienst trad. Vanaf 1923 waren er zeker al enige contacten. In 1925 had hij - onbezoldigd - een aantal artikelen geleverd. In februari 1927 werd hij aangesteld om een gedeelte van het redactiewerk op zich te nemen. Hij fungeerde ook als tussenpersoon en expert voor onderwerpen aangaande de Vlaamse beweging. ${ }^{36}$ Bij zijn dood in 1938 werkte hij nog steeds bij de krant, als bibliothecaris. ${ }^{37}$

Jozef Van den Broeck bleef gedurende zijn vrijwillige ballingschap in Nederland politiek actief als een anti-Belgische, Vlaams-nationalistische militant. Hij behoorde tot het Vlaamsch Comité dat als spreekbuis van de activistische ballingen moest optreden. ${ }^{38}$ In november 1918 reorganiseerde Josué De Decker het comité, de naam ervan werd vervlaamst tot Vlaamsch Komiteit en het werd uitgebreid met Arthur Claus, Reimond Speleers en Gustaaf Doussy. Ruzies over de te volgen strategie verlamden vanaf begin 1919 de werking van het comité. In maart 1919 werd het bestuur nogmaals hervormd; het bestond van dan af uit: De Decker, Ernest Van den Berghe, Van den Broeck, Raymond Brulez, Alfons Depla, Hippoliet Meert, Hendrik Mommaerts, Hector Plancquaert en De Vreese. ${ }^{39}$

Er is slechts een indicatie beschikbaar over de rol van Van den Broeck in het Vlaamsch Komiteit. Op een algemene vergadering van de uitgeweken activisten op 29 januari 1919 in het Zuid-Hollands Koffiehuis in Den Haag gaf hij een verslag van de commissie van Rechtswezen van het komiteit. ${ }^{40} \mathrm{Net}$ als tijdens de bezetting stelde hij zijn juridische knowhow in dienst van zijn politieke opties.

33. AMVC-Letterenhuis, Archief Jozef Van den Broeck, B8714: Brief Jozef Van den Broeck aan Adelfons Henderickx, 3 april 1925.

34. AMVC-Letterenhuis, Archief Jozef Van den Broeck, B8714: Brief Jozef Van den Broeck aan Adelfons Henderickx, 3 april 1925.

35. AMVC-Letterenhuis, Archief Jozef Van den Broeck, B8714: Brief Jozef Van den Broeck aan Adelfons Henderickx, 26 april 1925.

36. ADVN, Archief Jozef Van den Broeck, AC451, D1959(1), dossier De Residentiebode.

37. Volk en Staat, 1 december 1938.

38. Over de werking van het Vlaams comité zie J. Dedeurwaerder, Professor Speleers. Een biografie, Antwerpen-Gent, 2002, pp. 374-279.

39. P. van Hees, Vlaamsch Comité, in: R. De Schryver, e.a. (red.), NEVB [...] d dl. 3, p. 3373.

40. AMVC-Letterenhuis, Archief Raad van Vlaanderen, R1008, map 5. 
In België had intussen in 1919 het Vlaamse Front uiteindelijk gekozen voor politieke actie binnen het kader van de parlementaire democratie. Deze optie was echter niet onomstreden. Een aantal militanten zag er een acceptatie in van het gehate Belgische bestel. De radicalen bleven aansturen op een revolutionaire strategie gericht op de vernietiging van België en van de parlementaire democratie. Met name onder de activistische ballingen vond het revolutionaire gedachtegoed nogal wat aanhang. Hun zelfbeeld als Vlaamse voorhoede was immers moeilijk verzoenbaar met de rol van toeschouwer die de keuze voor de parlementaire weg onvermijdelijk met zich meebracht. De rancune over de mislukking van het activistische avontuur en de weerslag ervan op hun persoonlijk leven, had velen van hen buitendien in anti-Belgische richting geradicaliseerd. Zij werden hierin nog gestimuleerd door de invloed van rechtse Groot-Nederlandse Hollanders.

Zeker vanaf 1921 zwol de kritiek vanuit Nederland op de reformistische koers van de Frontpartij aan, te meer daar zij een klankbord vond bij ontevreden militanten in Vlaanderen. De partij werd politieke naïviteit verweten: langs parlementaire weg zou men niets voor Vlaanderen kunnen bereiken en de reformistische optie zou niet stroken met het revolutionaire anti-Belgische beginsel. ${ }^{41}$ Ook Jozef Van den Broeck liet zich niet onbetuigd bij de radicale kritiek vanuit Nederland. Zo was hij betrokken bij een poging om tot een overkoepelende organisatie van de radicale Vlaams-nationalisten in Nederland en België te komen. Hij was op 4 december 1921 aanwezig op de oprichtingsvergadering van het Verbond van Vlaamsche Nationalisten De Blauwvoet. Naast een aantal andere activistische ballingen, behoorden ook nationalisten uit België zoals Staf De Clercq, Albrecht Pil en Robrecht De Smet tot de oprichters. Het verbond streefde de vereniging van Nederland, Vlaanderen en Frans-Vlaanderen in een staat na en was antidemocratisch en autoritair van inslag. Het was dus de bedoeling een oppositiegroep te vormen tegen het gelaakte reformisme van de Frontpartij. ${ }^{42}$ Bleef in de praktijk de politieke spankracht van het geheime genootschap erg beperkt, via het weekblad Vlaanderen zou het milieu dat eraan ten grondslag lag, toch beslissende invloed uitoefenen op de ideologische ontwikkeling van het Vlaams-nationalisme.43

Ook speelde Van den Broeck een - zij het relatief beperkte - rol in het blad Vlaanderen. Hij verzorgde samen met Adolf Peremans de rubriek Briefuit Holland en schreef vanaf 1924 jarenlang de Brief uit Den Haag maar, zo vertrouwde hij Henderickx toe, hij deed dat vooral om zijn moeilijke financiële situatie ietwat te

41. L. Vandeweyer, De eerste barsten in het Vlaamse Front, in: Wetenschappelijke Tijdingen, jg. 44, 1985, nr. 2, p. 82; J. Dedeurwaerder, Professor [...] , pp. 425-428.

42. L. Vandeweyer, De eerste [...], p. 83.

43. L. Vandeweyer, Redaktiegeschiedenis van het weekblad "Vlaanderen" (1925-1934), in: Wetenschappelijke Tijdingen, jg. 45, 1986, nr. 2, pp. 65-83. 
verlichten. ${ }^{44}$ Het heeft er dus de schijn van dat financiële overwegingen niet afwezig waren bij zijn beslissing om politiek actief te blijven als publicist. De eerste Brief uit Den Haag verscheen in februari 1924 en handelde over een bezoek van Antoon Jacob aan Den Haag. ${ }^{45}$ Van dan af was de Haagsche Brief een vertrouwde rubriek in het blad. Hij kon over allerlei onderwerpen handelen, gaande van het sociale leven in Den Haag over de Nederlandse politiek tot de dood van de Amerikaanse president Wilson. ${ }^{46}$ Tot het einde van de jaren 1920 zou Van den Broeck blijven meewerken aan Vlaanderen. Zijn stukken dienden de politieke finaliteit van het blad. Zo ging vanaf 1925 de aandacht in zijn Haagsche brief bijna uitsluitend naar het Belgisch-Nederlandse verdrag over de waterwegen. Hij ondersteunde, net als andere activistische ballingen, de campagne van Nederlandse tegenstanders van het verdrag uit de Rotterdamse zakenwereld en het Hollandse Groot-Nederlandse milieu. Van den Broeck hanteerde de vertrouwde Groot-Nederlandse retoriek om zijn lezers tegen het verdrag én tegen België op te zetten. België werd afgeschilderd als een annexionistische, anti-Nederlandse staat die bovendien een werktuig van Frankrijk was. Ieder verdrag dat het zou versterken, diende dan ook als een gevaar voor Nederland bestreden te worden. ${ }^{47}$ Antwerpenaar Van den Broeck was blijkbaar dermate vervuld geraakt van het Groot-Nederlandse argumentarium dat hij er geen graten in zag een verdrag te bestrijden dat onontbeerlijk was voor de economische ontwikkeling van zijn moederstad.

Van den Broecks participatie in de strijd tegen het verdrag - tegen de belangen van Antwerpen in - illustreert duidelijk dat het antibelgicisme voor hem primeerde boven alles. Hoezeer de overtuiging dat België vernietigd diende te worden, het sluitstuk vormde van zijn politieke handelen, blijkt wel uit een tekst die op 2 juli 1927 in Vlaanderen verscheen. Van den Broeck vergeleek daarin zichzelf, als onvermoeibaar strijder tegen zijn vijand, namelijk België, met Cato: "Dus Ceteris paribus, zou ik Cato's lijfspreuk willen overnemen en hem ten opzichte van België aanwenden, als een belijdenis..., wat dan Belgicam esse delendam zou moeten worden. ${ }^{\prime 48} \mathrm{Om}$ zijn politiek programma te realiseren, rekende Van den Broeck niet op het Vlaamse Front. Toen een journalist van La Meuse hem in oktober 1922 vroeg welke volksvertegenwoordiger zijn opinies deelde, antwoordde hij: "Je ne vois personne à la chambre." 49

44. L. Vandeweyer, Machtsstrijd in het Vlaamse Front. Het afsterven van "Ons Vaderland", de geboorte van "Vlaanderen", in: Wetenschappelijke Tijdingen, jg. 44, 1985, nr. 4, pp. 214 en 221.

45. Vlaanderen, 2 februari 1924.

46. Vlaanderen, 29 maart 1924 en 5 april 1924.

47. Haagsche Brief XXV, in: Vlaanderen, 17 oktober 1925. Over dat verdrag en zijn bestrijding:

L. Wils, Burgemeester Van Cauwelaert, schepper van Nederlandstalig Vlaanderen 1923-1932, Antwerpen-Amsterdam, 2005, pp. 83-116.

48. Brief uit Den Haag, in: Vlaanderen, 2 juli 1927.

49. Les activistes en exil, in: La Meuse, 3 oktober 1922. 
Van den Broeck was ook actief in het verenigingsleven van de gevluchte activisten in Nederland. Het duurde enige tijd vooraleer de ballingen tot de vorming van verenigingen overgingen. De opbouw van een nieuw bestaan in Nederland slorpte bij velen zoveel energie op, dat nauwelijks ruimte voor andere bezigheden restte. Pas in 1921 duiken de eerste tekenen op dat Jozef Van den Broeck na de ontbinding van het Vlaamsch Komiteit weer geregelde samenkomsten van activistische ballingen in Den Haag bijwoonde. De club De Pallieters organiseerde toen elke vrijdag een bijeenkomst in het Zuid-Hollands Koffiehuis. Voordien had er ook al enige tijd een dergelijke club bestaan, maar die was stilgevallen bij het ontstaan van Voor Vrij Vlaanderen. ${ }^{50}$ Deze laatste vereniging bestond uitsluitend uit gevluchte activisten en deed niet veel meer dan de jaarlijkse elfjuliviering organiseren. ${ }^{51}$

Jozef Van den Broeck raakte later ook betrokken bij de Haagse afdeling van het ANV. Hij gaf in 1923 voor de jongerenafdeling twee toespraken over de geschiedenis van de Vlaamse beweging. ${ }^{2}$ Op het 25 -jarige jubileum van het ANV in 1923 gaf hij een toespraak over Hippoliet Meert, de oprichter van het ANV. ${ }^{53}$ Het ANV in Den Haag onder leiding van kapitein Karel Oudendijk had overigens al vrij snel na de oorlog de banden met de gewezen activisten aangehaald. Met Oudendijk en Marcel Emants ${ }^{54}$ in hun rangen en met de steun van Frederik Carel Gerretson werd de Haagse afdeling de motor van de Groot-Nederlandse anti-Belgische beweging in Nederland. ${ }^{55}$ Tot ongenoegen van het hoofdbestuur, vierde het Haagse ANV al in 1919 samen met de activistische ballingen de herdenking van de Guldensporenslag. Een jaar later was de afkeer van het hoofdbestuur ten opzichte van de gewezen activisten al wat getemperd. Van den Broecks voorzitterschap van het organisatiecomité van de Guldensporenherdenking van 1923 geeft zijn prominente positie binnen de activistische ballingengemeenschap in Den Haag aan. ${ }^{56}$

Een beslissende impuls naar een meer gestructureerd verenigingsleven kwam er met de eerste begroetingsdag, gehouden in Hansweert in Zeeland op 12 augustus $1923 .{ }^{57}$ Gewezen activisten uit Nederland en sympathisanten uit Vlaan-

50. ADVN, Archief Jozef Van den Broeck, AC451, D1959(1), dossier De Pallieters. Zie ook J. Dedeurwaerder, Professor [...], pp. 414-416.

51. N. Van Campenhout, Balling in Nederland. Een hoofdstuk uit het leven van Karel Heynderickx (1918-1929), in: Wetenschappelijke Tijdingen, jg. 38, 1979, nr. 3, p. 153.

52. Brief uit Den Haag, in: Vlaanderen, 5 april 1924; ADVN, Archief Jozef Van den Broeck, AC451, D1959(1), dossier ANV.

53. Vlaanderen, 9 juni 1923 en 16 juni 1923.

54. Over Emants schreef Van den Broeck in 1923 overigens een stukje in Neerlandia, waarin hij diens radicaliteit aanprees: J. Van den Broeck, Marcellus Emants en het A.N.V., in: Neerlandia, jg. 27, 1923, nr. 12, p. 172.

55. L. Wils, Vlaanderen [...], p. 285.

56. Guldensporenherdenking in Holland, in: Vlaanderen, 28 juli 1923.

57. Over de begroetingsdagen zie L. Molenaar, Marcel Minnaert. Astrofysicus 1893-1970. De rok van het universum, Amsterdam, 2003, pp. 160-161. 
deren kwamen er samen. De politieke betekenis van dergelijke begroetingsdagen bestond erin de rol van de oud-activisten binnen het Vlaams-nationalisme te beklemtonen. Het vormde een gelegenheid voor de bannelingen om vertegenwoordigers van het Vlaamse Front te ontmoeten. Van den Broeck had de ontmoetingsdag vooraf geen goed idee gevonden. Hij drukte het tegen Henderickx zo uit: “Wij hebben hier de gunstige positie met grote moeite en geduld (en geluk!) veroverd dan dat wij voor ene nutteloze plezierpartij die in gevaar zouden brengen. ${ }^{158} \mathrm{Hij}$ vond dat het de goede betrekkingen met de Nederlandse overheid nodeloos zou belasten. De manifestatie en de aandacht die het in de pers zou krijgen zou volgens hem de Nederlandse overheid onder druk kunnen zetten om haar houding tegenover de activisten te herzien. Zijn protest mocht niet baten; de begroetingsdag ging gewoon door. Van den Broeck polste zijn contacten in de Nederlandse politiediensten over de begroetingsdag. Ook intervenieerde hij op aanvraag van Marcel Minnaert, de organisator van het gebeuren, om de benodigde reispermissies te bekomen bij het Ministerie van Buitenlandse Zaken. Achteraf kon hij aan Minnaert meedelen dat er van overheidswege niets ondernomen zou worden, maar wel toezicht zou gehouden worden. ${ }^{59} \mathrm{Hij}$ zag dat als het resultaat van zijn bemoeienissen. De begroetingsdag werd een succes. Driehonderd Vlamingen uit Aalst en Gent waren met een speciale boot naar Hansweert gekomen. ${ }^{60}$ De begroetingsdag groeide uit tot een jaarlijks terugkerende hoogdag voor de uitgeweken activisten. ${ }^{61}$

Uit de organisatie van de eerste begroetingsdag werd een week nadien in Den Haag de vereniging Hou ende Trou opgericht, met Flor Heuvelmans als voorzitter. Ook Van den Broeck werd er lid van. De bedoeling van de vereniging was een einde te stellen aan de onenigheid die er bestond tussen de bannelingen en te komen tot de coördinatie van hun politieke initiatieven. Onder andere via Henderickx werd samenwerking met het Vlaamse Front in het vooruitzicht gesteld. Daarnaast poogde de vereniging met cultureel-politieke avonden, de Vlaamse en Groot-Nederlandse beweging onder de aandacht van het Nederlandse publiek te brengen. In november 1923 werd de vereniging officieel boven de doopvont gehouden. ${ }^{62}$ Nederlanders bleken echter niet erg happig om zich rechtstreeks te verbinden met uitgeweken collaborateurs. Pas nadat Hou ende Trou zich verruimde tot een Vlaams-Hollandse vereniging, groeide de Neder-

58. AMVC-Letterenhuis, Archief Jozef Van den Broeck, B8714: Brief van Jozef Van den Broeck aan Adelfons Henderickx, 25 juli 23.

59. ADVN, Archief Jozef Van den Broeck, AC451, D1959(2), dossier begroetingsdagen: Brieven tussen Minnaert en Jozef Van den Broeck, 8 augustus 1923 en 10 augustus 1923.

60. AMVC-Letterenhuis, Archief Jozef Van den Broeck, B8714: Brief van Jozef Van den Broeck aan Adelfons Henderickx, 23 augustus 1923.

61. Vlaanderen, 30 juli 1927.

62. AMVC-Letterenhuis, Archief Jozef Van den Broeck, B8714: Brief van Jozef Van den Broeck aan Adelfons Henderickx, 23 november 1923. 
landse inbreng. ${ }^{63}$ Ook in Rotterdam en in Utrecht werden Vlaams-Hollandse verenigingen opgericht. Op 15 november 1924 werd er een overkoepelend verbond van Vlaams-Hollandse Verenigingen in Holland opgericht.

In januari 1929 keurde de Belgische Senaat een amnestiewet goed, de zogenaamde 'genadewet' of 'uitdovingswet'. Volledige amnestie hield die wet niet in. De activistische ballingen mochten wel terugkeren, maar zij die tot tien jaar of meer veroordeeld waren, kregen hun burgerrechten niet terug. Van den Broeck die ter dood veroordeeld was, kwam dus niet in aanmerking. Uit een toespraak voor Hou ende Trou, einde juli 1929, blijkt dan ook dat Van den Broeck niet tevreden was met de amnestieregeling, want ze verstrekte alleen clementie en schafte de straf niet af. ${ }^{64}$ De uitdovingswet leidde ertoe dat velen terugkeerden naar België, maar de strengst gestraften, zoals Van den Broeck, bleven veelal in Nederland. ${ }^{65}$ De verbittering die hij voelde tegenover België en zijn intussen geslaagde integratie in Nederland zullen daarbij wel een rol hebben gespeeld. Hij bleef werkzaam bij $D e$ Residentiebode en bleef tot zijn overlijden in november 1938, actief in het Vlaamse verenigingsleven, zij het niet meer op de voorgrond.

\section{EEN INFORMANT IN NEDERLANDSE DIENST}

Tijdens de Eerste Wereldoorlog was Van den Broeck opgetreden als verbindingsman tussen de Raad van Vlaanderen en de bezetter. Na de oorlog zou hij een vergelijkbare functie uitoefenen in Nederland. Hij ontpopte er zich tot de contactpersoon tussen de activistische ballingen en de Nederlandse overheid.

In Nederland bevonden zich einde januari 1919 ongeveer honderdvijfenzeventig tot tweehonderd Vlaams-nationalistische ballingen. Duitsland herbergde in de buurt van Düsseldorf, in Bad Salzuflen, einde december een honderddertigtal vluchtelingen. ${ }^{66}$ De Duitse overheden moedigden hen financieel aan om de wijk te nemen naar Nederland, wat de meerderheid van hen ook deed. ${ }^{67}$ Uiteindelijk nam Nederland ongeveer vijfhonderd activistische ballingen op. ${ }^{68}$ Vertaald naar hedendaagse termen, kunnen ze met recht als politieke vluchtelingen betiteld worden. De gewezen collaborateurs riskeerden immers de doodstraf, gevangenisstraf of ontslag als ze naar België zouden terugkeren. De Nederlandse overheid

63. N. Van Campenhout, Balling [...], pp. 153-155. Zie ook Haagsche Brief, in: Vlaanderen, 17 oktober 1925.

64. Vlaanderen, 30 juli 1929.

65. P. van Hees, Vlaamse activisten als politieke vluchtelingen in Nederland tijdens het interbellum, in: Tijdschrift voor Geschiedenis, jg. 100, 1987, nr. 3, p. 408.

66. Voor de uitwijking van activisten naar Duitsland: W. Dolderer, Deutscher [...], pp. 226-231. 67. W. Dolderer, Activistische ballingen in Duitsland na de Eerste Wereldoorlog, in: Wetenschappelijke tijdingen, jg. 59, 2000, nr. 2, p. 73.

68. D. Vanacker, Het aktivistisch [...], pp. 350-351. 
bood hun politiek asiel aan als ze aan bepaalde voorwaarden voldeden. ${ }^{69}$ De vluchteling moest kunnen aantonen dat hij inderdaad asiel nodig had om hem te vrijwaren van politiek geïnspireerde vervolging. In concreto moest hij dus een bewijs kunnen leveren van activistische activiteiten tijdens de bezetting. De Nederlandse overheid begreep dat zijzelf niet in staat was om op afdoende wijze in te schatten of iemand tijdens de oorlog activist was geweest of niet. Medewerking van de Belgische overheden viel in deze om evidente redenen niet te verwachten. De Nederlandse overheid had ter staving van de verklaringen van de vluchtelingen nood aan informanten die op de hoogte waren van de interne keuken van het activisme. Jozef Van den Broeck was de geknipte figuur om de asielaanvragen op hun merites te beoordelen. Het valt uit de beschikbare documenten niet op te maken waarom en vanaf welk ogenblik precies de Nederlandse autoriteiten een beroep deden op Van den Broeck. Van den Broeck lag als voormalig secretaris van de Raad van Vlaanderen, bevoegd voor relaties met de Duitse overheid, wel sterk voor de hand. Het feit dat hij in Den Haag was gaan wonen, waar ook de vreemdelingendienst gevestigd was, maakte de samenwerking ook praktisch mogelijk.

Van den Broeck stond in voor een grondig onderzoek van de achtergrond van elke vluchteling die wegens een activistisch verleden aanspraak meende te kunnen maken op politiek asiel. Aangezien hij zelf natuurlijk niet elke voormalige activist kende, maakte hij op zijn beurt gebruik van een netwerk van vertrouwensmannen over het gehele Nederlandse grondgebied. Na onderzoek moest hij een advies formuleren over de vraag of deze persoon al dan niet in aanmerking kwam voor politiek asiel. Zijn grondige aanpak leidde ertoe dat zijn mening zwaar doorwoog in het uiteindelijke besluit van de overheid.

Bij de formulering van zijn advies diende Van den Broeck een aantal criteria in acht te nemen. Een belangrijk punt was de aankomstdatum van de vluchteling in Nederland. Al wie voor 15 november 1918 in Nederland aangekomen was en er sindsdien onafgebroken gewoond had, kwam in aanmerking voor een verblijfsvergunning van onbepaalde duur. In de praktijk haalden vooral de grote vissen van bijvoorbeeld het Vlaamsch Komiteit voordeel uit deze bepaling, omdat zij doorgaans sneller de benen hadden genomen dan de kleine garnalen. Wie na deze datum in Nederland toegekomen was, kon geen aanspraak maken op een verblijfsvergunning van onbepaalde duur, maar moest het stellen met voorlopige passen, die geregeld hernieuwd dienden te worden. ${ }^{70}$

69. P. van Hees, Vlaamse [...], pp. 399-400.

70. ADVN, Archief Jozef Van den Broeck, AC451, D1957(2), dossier vreemdelingendienst: Nota van het rijkspaspoortenkantoor, Imhoffplein aan Jozef Van den Broeck (ontvangen 28 februari 1923). 
Afgezien van deze specifieke regeling dienden de activistische ballingen te beantwoorden aan de gebruikelijke verblijfsvoorwaarden voor vreemdelingen in Nederland:

- In het bezit zijn van een bewijs van tewerkstelling, waarbij de werkgever de aard van het werk meedeelde en er zich toe verbond het einde van het dienstverband mee te delen.

- In het bezit zijn van een bewijs dat er geen Nederlandse werkkrachten in staat zijn de arbeidsplaats van de vluchteling in te nemen.

- Geen bezwaar hebben tegen een eventuele begeleide terugkeer naar het land van herkomst.

- In het bezit zijn van een getuigschrift van het hoofd van de lokale politie waarin hij verklaart geen bezwaar te hebben tegen het verblijf in de gemeente. ${ }^{71}$

Voldeed een vluchteling aan deze voorwaarden, dan kon hij vrij beschikken. Was dit niet het geval, dan werd hij geïnterneerd. Activistische vluchtelingen zonder middelen van bestaan werden na aankomst ondergebracht in een interneringskamp in Harderwijk.

Van den Broeck werd niet enkel door de Nederlandse overheden ingeschakeld om de achtergrond van gewezen activisten na te gaan. Vanwege zijn uitstekende contacten met de Nederlandse autoriteiten deden de vluchtelingen een beroep op hem om allerlei problemen van administratieve aard op te lossen. Bij de vreemdelingendienst ${ }^{72}$ die zich op het Imhoffplein in Den Haag bevond, was Van den Broeck dan ook geen onbekende figuur. Hij kwam er geregeld over de vloer om paskwesties te regelen voor de vluchtelingen. Hij werd er blijkbaar na verloop van tijd zo vaak gezien dat men begon te vrezen dat de buitenwereld lucht zou krijgen van zijn activiteiten. Het gevaar bestond dat hij beschouwd zou worden als agent van hulpinspecteur De Marez Oyens wat zijn activiteiten in het gedrang zou kunnen brengen. Discretie was voor delicaat inlichtingenwerk als het zijne, immers een noodzakelijke voorwaarde. Om niet nodeloos de aandacht op zijn persoon te vestigen, vroeg Van den Broeck vanaf 20 april 1919 dat de vluchtelingen zelf hun zaak aanhangig zouden maken bij de vreemdelingendienst nadat zij voorgelicht waren en een aanbeveling van Van den Broeck hadden meegekregen.73

Van den Broeck heeft van zijn werk als contactpersoon tussen de Vlaamse vluchtelingen en de Haagse vreemdelingendienst een tweehonderdtal dossiers bijgehouden. Hij werkte zeer toegewijd aan de creatie en de instandhouding van de vertrouwensrelatie die ontstaan was tussen de bevoegde diensten en de Vlaamse ballingen. Van den Broeck stond erop een grondig onderzoek uit te voeren voor-

71. ADVN, Archief Jozef Van den Broeck, AC451, D1957(2), dossier vreemdelingendienst. 72. ADVN, Archief Jozef Van den Broeck, AC451, D1957(2), dossier vreemdelingendienst. 73. ADVN, Archief Jozef Van den Broeck, AC451, D1957(2), Brief van Jozef Van den Broeck aan prof. J. De Decker, 20 april 1920. 
aleer een vluchteling aan te bevelen bij de vreemdelingendienst. Misdadigers van gemeen recht of economische vluchtelingen mochten niet mee profiteren van de gastvrijheid die Nederland de Vlaamse activisten verleende. Mocht blijken dat de aanbevelingen al te kwistig rondgestrooid werden, dan zou dit de zaak van alle echte politieke vluchtelingen schaden. In een brief aan de te onachtzame Arthur Van de Kerckhove formuleerde Van den Broeck het zo: "Het is in het belang van ons allen, vermits Nederland des te gemakkelijker en breder het asielrecht vergunnen kan, als het op de inlichtingen en aanbevelingen die ik verschaf met gerustheid bouwen kan." 74 De accuratesse van Van den Broeck heeft ervoor gezorgd dat er zich zelden problemen voordeden en dat het overgrote deel van de activisten zich weinig zorgen hebben moeten maken over een mogelijke gedwongen terugkeer naar het vaderland. Pogingen van de Belgische staat om activisten te doen uitleveren, liepen op niets uit. Het Belgische gerecht had vergeefse stappen gezet om de Gentse professoren Van den Berghe, Van Roy en De Vreese te laten uitleveren. Voortgaand op zijn contacten met de Nederlandse overheid, was Van den Broeck zeer optimistisch over de Nederlandse houding op lange termijn ten opzichte van de activisten. In zijn dagboek noteerde hij in april 1920: "Ik heb de overtuiging dat Nederland tot het bittere einde toe het asielrecht voor ons handhaven zal. Doch onze verhouding tot Nederland zal op den duur nopen tot omzichtigheid vrees $i k(.$. Nederland heeft er blijk van gegeven dat het op het stuk van politieke gastvrijheid ten volle zijn plicht vervullen wil. En het vervult het dien ook met flinkheid, met zwier."75

Het wedervaren van de Vlaamse ballingen is ook in andere opzichten vergelijkbaar met de situatie van hedendaagse politieke vluchtelingen. Naast het probleem van het statuut, zorgde vooral de zoektocht naar bestaansmiddelen voor kopzorgen. Het vinden van een baan vormde voor de gevluchte activisten de enige structurele oplossing om in hun levensonderhoud te kunnen voorzien. Van den Broeck droeg ook op dit vlak een steentje bij om de integratie van de ballingen in de Nederlandse samenleving te begeleiden, hoewel het hem persoonlijk ook niet voor de wind ging.

Het vreemdelingenreglement stipuleerde dat een vreemdeling geen werk van een Nederlander mocht afnemen. Vooral laagopgeleiden hadden te kampen met die bepaling. Gediplomeerde vluchtelingen werden dan weer geconfronteerd met het probleem dat hun Belgische diploma in Nederland niet erkend werd. Het overdoen van de opleiding aan een Nederlandse universiteit was dan de enige optie.

74. ADVN, Archief Jozef Van den Broeck, AC451, D1958(1), dossier Moulinas: Afschrift van de brief van Jozef Van den Broeck aan Van de Kerckhove, 1 augustus 1920.

75. ADVN, Archief Jozef Van den Broeck, AC451, D1957(1): Dagboek Jozef Van den Broeck, 17 april 1920. 
Om de integratie van de activisten in de Nederlandse arbeidsmarkt te begeleiden, werd door medewerkers van het Vlaamsch Komiteit een zogenaamde 'werkbeurs' opgericht. Van den Broeck nam gedurende een tijd het voorzitterschap waar. Leo Meert had hem hiervoor aangezocht. Hij verving Hector Plancquaert die zich onvoldoende ingezet zou hebben. Van den Broeck sprak al zijn contacten aan om werk te vinden voor de ballingen. Zoals uit zijn dagboek blijkt, mobiliseerde hij ook de relaties die hij tijdens de bezetting in het kader van de Flamenpolitik had opgebouwd: "Zo-even bezocht ik den heer Jost, een Duitscher die bij de Zivilverwaltung werkte te Antwerpen...Hij zou mij sommige personen voor diensten aanbevelen en wederkerig trachten onze vrienden betrekkingen te verschaffen. ${ }^{176}$ Waarschijnlijk werd ook een beroep gedaan op invloedrijke kennissen uit de Groot-Nederlandse beweging.

Sommige Vlaamse activisten waren na hun vlucht beland in het interneringskamp van Harderwijk. Ze konden eenmaal ze er verzeild waren geraakt, het kamp enkel nog verlaten als ze een bewijs van tewerkstelling van de districtsarbeidsbeurs hadden, of als ze in het bezit waren van 250 gulden. Sommigen waren er na meer dan een jaar internering nog steeds niet in geslaagd hieraan te voldoen. Van den Broeck kon bijvoorbeeld weinig doen voor Frans De Vocht, deserteur en activistisch propagandist tijdens de oorlog. Hij was namelijk sigarenmaker en die had men al genoeg in Nederland, waardoor hij zeer moeilijk werk kon vinden.77 Naast De Vocht bevonden er zich een jaar na de wapenstilstand nog ten minste vier andere gewezen activisten in het kamp. Van den Broeck poogde voor de anderen ook in te grijpen, maar het probleem was dat het laagopgeleiden waren die weinig kansen hadden op de arbeidsmarkt. Het probleem werd urgent toen bleek dat sommige Vlaamse gevangenen een ontsnappingspoging hadden ondernomen. ${ }^{78}$

Van den Broeck stond die eerste Nederlandse jaren niet alleen in verbinding met de Nederlandse overheid via de vreemdelingendienst, maar ook met agenten van de politieke recherche. In 1923 zocht de politieke afdeling van de recherche in Den Haag in de persoon van inspecteur Pool contact met hem. Op hun eerste ontmoeting op 26 juli 1923 spraken ze af informatie uit te wisselen..$^{79}$ De aanleiding tot de samenwerking was de gespannen verhouding tussen Nederland en België in de naoorlogse periode. ${ }^{80}$ De Nederlandse overheid was erg beducht

76. ADVN, Archief Jozef Van den Broeck, AC451, D1957(1), Dagboek Jozef Van den Broeck, 6 januari 1920 en 11 maart 1920.

77. ADVN, Archief Jozef Van den Broeck, AC451, D1957(2), dossier Frans De Vocht.

78. ADVN, Archief Jozef Van den Broeck, AC451, D1957(2), dossier Geïnterneerden.

79. ADVN, Archief Jozef Van den Broeck, AC451, D1957(2), dossier Veiligheid: Verslag gesprek met Pool, 26 juli 1923.

80. Zie voor de doorwerking van de Eerste Wereldoorlog op de Belgisch-Nederlandse relaties: M. De Waele, Nederland-Vlaanderen: periode vanaf 1914, in: R. De Schryver, e.a. (red.), NEVB [...], dl. 2, pp. 2171-2177. 


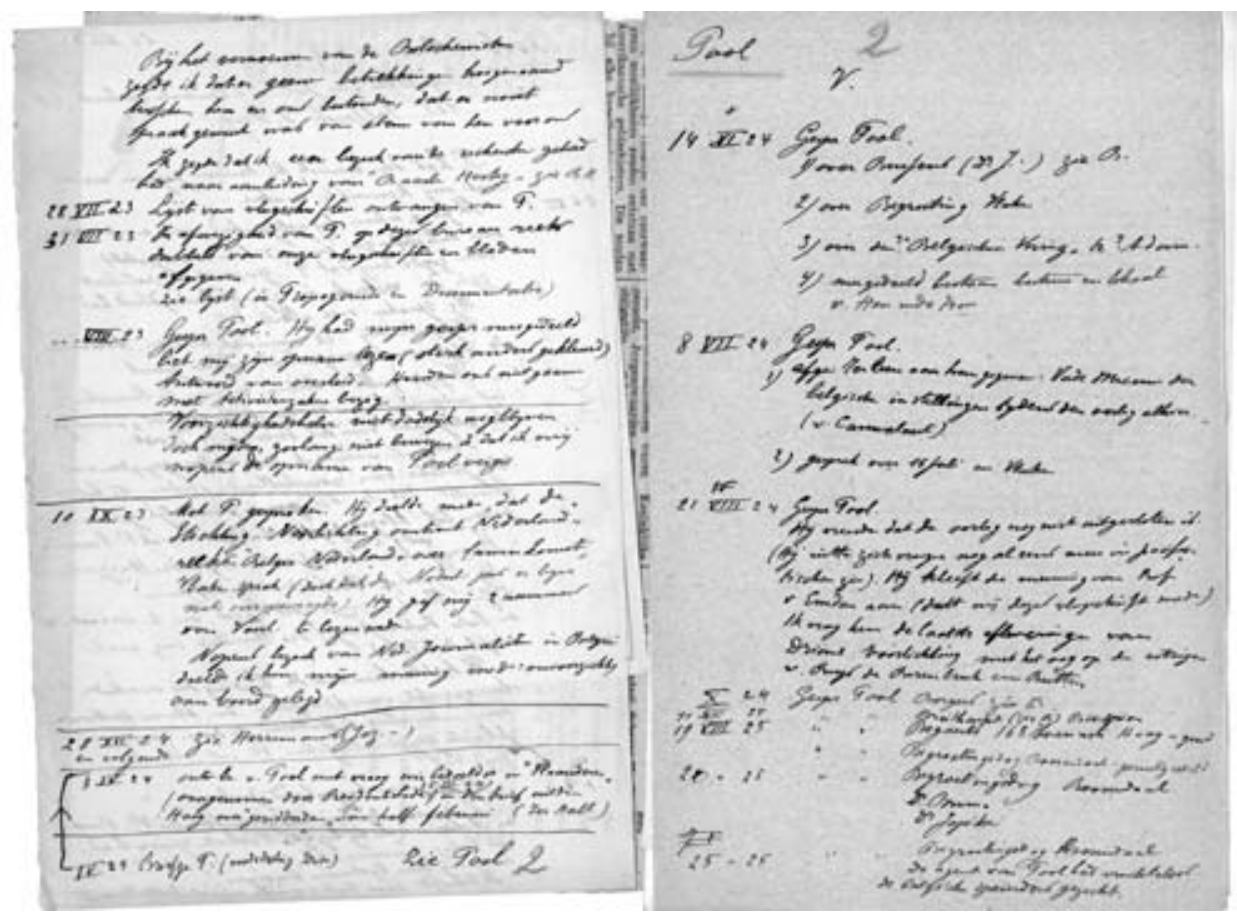

Verslag van de gesprekken met inspecteur Pool, opgesteld door Jozef Van den Broeck, 1923-1925.

[ADVN, BE ADVN AC451 - Archief Jozef Van den Broeck, D1957(2)]

voor mogelijke Belgische spionnen. De activisten konden behulpzaam zijn bij de opsporing van Belgische vertrouwensmannen. Bovendien stond de Nederlandse overheid in het licht van de Russische Revolutie erg argwanend tegenover nieuwe vluchtelingen. De vrees voor infiltratie door buitenlandse communisten zat er diep in. Die angst werd nog versterkt door Belgische patriottische bladen als La Nation belge die een amalgaam maakten van communisme en activisme. ${ }^{81}$ Socialistische of communistische activisten wekten dan ook in toenemende mate bezorgdheid bij de Nederlandse inlichtingendiensten.

Inspecteur Pool wilde op die eerste ontmoeting in eerste instantie weten welke activisten er zich in Den Haag bevonden en welke bladen zij uitgaven. Verder wenste hij opheldering over de mogelijke aanwezigheid van bolsjewieken onder de activisten en over de zaak 'Baarle-Hertog'. De aanleiding van de zaak 'Baarle Hertog' was een uit de hand gelopen grap, die beroering tot in de top van het Nederlandse repressieapparaat verwekte. De vrees bestond namelijk dat oudactivisten een aanslag zouden willen plegen in de Belgische enclave Baarle-Hertog.

81. P. van Hees, Vlaamse [...], p. 403. 
Zij kwam voort uit een schertsend gesprek in "onze gezellige bijeenkomst in het ZuidHollandse koffiehuis" in Den Haag. Iemand moet blijkbaar dit grapje serieus hebben genomen en het doorgespeeld hebben naar de politie, die het een onderzoek waard vond. ${ }^{82}$

Van groter belang was de verdenking dat er zich communisten onder de activistische ballingen zouden bevinden. In een brief van Lambrecht Jagenau aan Van den Broeck van 5 maart 1919 wordt aangehaald dat er sympathie bestond onder de Nederlandse elites ten aanzien van de activisten, maar dat de verdenking van bolsjewisme die positieve grondhouding in het gedrang dreigde te brengen. Concrete incidenten wakkerden de onrust onder de Nederlandse elites aan. Alexis Heylen werd bijvoorbeeld in 1919 aan de grens met Duitsland betrapt met een schema van een rede over het communisme, gehouden in Bad Salzuflen. Dit zal de Nederlandse autoriteiten op zijn minst de wenkbrauwen hebben doen fronsen en een verder onderzoek naar de mogelijke communistische infiltratie hebben bespoedigd. Uit het archief van Van den Broeck kunnen we bijvoorbeeld opmaken dat J. Bussens onderwerp van dergelijk onderzoek geweest was. ${ }^{{ }^{3}}$

Van den Broeck verstrekte ook inlichtingen aan de Nederlandse diensten inzake de Belgische politiek ten aanzien van Nederland en de activiteiten van Belgische agenten in Nederland. Op 28 december 1923 vroeg Pool in een gesprek met Van den Broeck diens hulp in verband met mogelijke stukken die konden wijzen op annexionisme van Belgische kant. Het zou gaan over stukken van de Belgische overheid, overgemaakt aan de Belgische generaals in bezet Duits gebied. Jozef Herremans uit Maastricht zou in het bezit zijn van deze documenten. Van den Broeck zei hulp toe en ging midden januari samen met Spincemaille, Herremans bezoeken. Herremans zei dat hij inderdaad die stukken in bezit had gehad, en dat hij een afschrift zou sturen naar Van den Broeck. Of die inderdaad zijn toegekomen en of die ooit Pool bereikt hebben, kan niet opgemaakt worden. ${ }^{84}$ In april-mei 1926 zou Van den Broecks netwerk helpen in een onderzoek naar zogenaamde 'activistenjagers'. G.H.J. Nieuwenhuijs, de opvolger van Pool, vroeg Van den Broeck toen inlichtingen in verband met de personen Van Herwegen, Moors en Mirguet, mogelijk Belgische agenten. Na inschakeling van Thielemans, Angermille en Spincemaille kon aan het verzoek op 6 mei voldaan worden. ${ }^{85}$

Van Nederlandse zijde kreeg Van den Broeck dan weer informatie in verband met een verzamelplaats van Belgische spionnen in het hotel Astoria in Den Haag. Pool zou op vraag van Van den Broeck ook de Nederlandse overheden polsen over de ontmoetingsdagen die in 1923 voor het eerst gehouden werden.

82. ADVN, Archief Jozef Van den Broeck, AC451, D1957(2), dossier Veiligheid: Baarle-Hertog. 83. ADVN, Archief Jozef Van den Broeck, AC451, D1957(2), dossier Veiligheid: Bussens, J. 84. ADVN, Archief Jozef Van den Broeck, AC451, D1957(2), dossier Veiligheid: Herremans Jozef. 85. ADVN, Archief Jozef Van den Broeck, AC451, D1957(2), dossier Veiligheid: Van Herwegen. 
BESLUIT

De Eerste Wereldoorlog zorgde voor een dramatische wending in het leven van de Antwerpse katholieke flamingant Jozef Van den Broeck. Voor 1914 was de toen 44jarige advocaat actief als een militant, die streefde naar de geleidelijke realisatie van zijn idealen langs parlementaire weg en steunend op de volkswil. Het perspectief van een snelle doorbraak door te steunen op het dictatoriale gezag van de bezetter, deed hem dit spoor verlaten, waardoor de band met de bevolking doorgesneden werd. Al vroeg tijdens de bezetting opteerde hij voor de collaboratie waarin hij een prominente rol zou spelen en waarvan hij uiteindelijk zijn broodwinning maakte. Net als bij andere activisten het geval was, leidde de keuze voor de collaboratie bij Van den Broeck tot verwarring tussen doel en middelen wat hem enkel verder isoleerde. Zo was hij bereid in het vermeende belang van Vlaanderen het perspectief van een blijvende Duitse bezetting te slikken.

Toen de basis van de activistische machtspolitiek door de Duitse ineenstorting weggeslagen werd, nam Van den Broeck de wijk naar Nederland waar hij actief bleef als nationalistisch militant. Anders dan voor de oorlog toen zijn handelen gericht was op de realisatie van zijn program langs parlementaire weg, bestreed hij door het propageren van een steil antibelgicisme elke constructieve vooruitgang in het parlement. Weer was er sprake van verwarring van doel en middelen; in naam van de Vlaamse zaak bestreed Van den Broeck verdragen die onontbeerlijk waren voor de welvaart en het welzijn van zijn stad van herkomst. Van den Broecks kennis van het activistische milieu maakte van hem een geschikte informant voor de Nederlandse overheden die controle wensten te krijgen over de instroom van politieke vluchtelingen uit België. Via het inlichtingennetwerk dat hij opbouwde, kon hij hun betrouwbare informatie verstrekken om infiltratie door communistische agitatoren en Belgische agenten tegen te gaan.

Yves Geenen (1977) is licentiaat in de geschiedenis (Katholieke Universiteit Leuven). Antoon Vrints (1978) is doctor in de geschiedenis (Universiteit Gent) en publiceerde over het activisme, de Duitse minderheden in België en (politiek) geweld. Hij is momenteel als projectmedewerker verbonden aan het ADVN. 


\section{ABSTRACT}

Geenen (Yves) \& Vrints (Antoon), Jozef Van den Broeck, flamingant en informant (1870-1938), in: Wetenschappelijke tijdingen, LXV, 2006, 3, pp. 174-195.

Yves Geenen \& Antoon Vrints, Jozef Van den Broeck, Supporter of the Flemish Movement and Informer (1870-1938)

The militant for language rights Jozef Van den Broeck (1870-1938) developed his Flemish radical itinerary departing from the radical democratic atmosphere of the Nederduitsche Bond, which he himself summarised with the slogan Belgicam esse delendam, paraphrasing a quotation of the Roman orator Cato. Yves Geenen and Antoon Vrints describe how Van den Broeck evolved during the First World War towards activism, as the secretary of the Council of Flanders. His knowledge of the circle of activists and his experience as a contact person with the authorities served him well, when he was granted political asylum in the Netherlands after he had been sentenced to death after the war. There he acted as a mediator between the Dutch authorities and the refugee activists. 